\title{
NEW OCCURRENCE OF LEPISOSTEID REMAINS (LEPISOSTEIFORMES: LEPISOSTEOIDEA) FROM THE CENOMANIAN OF THE ALCANTARA FORMATION (UPPER CRETACEOUS), MARANHÃO STATE, BRAZIL
}

\author{
Erick Ribeiro-Souza $^{1}$ (D), Ana Caroline Carvalho Araújo ${ }^{1}$ (D), Rafael Matos Lindoso ${ }^{\text {(iD }}$ \& Manuel Alfredo \\ Medeiros ${ }^{1}$
}

${ }^{1}$ Universidade Federal do Maranhão, Departamento de Ciências Biológicas e da Saúde, campus do Bacanga, Avenida dos Portugueses, s/n, CEP: 65.085-580 São Luís, MA, Brasil.

${ }^{2}$ Instituto Federal do Maranhão, campus São Luís Monte Castelo, Avenida Getúlio Vargas, ${ }^{\circ}$ 04, Monte Castelo, CEP: 65.030-005, São Luís, MA, Brasil.

\begin{abstract}
Lepisosteoidea is a superfamily of Lepisosteiformes. Its representatives, popularly known as gars, are divided in two families: Lepisosteidae and Obaichthyidae. The Alcântara Formation (Cenomanian) outcroppings discovered along the Maranhão state coast in Northeastern Brazil revealed a diverse ichthyofauna, at which the Lepisosteiformes occurrence was attributed to Lepidotes sp. based on morphological descriptions of isolated ganoid scales. Herein we describe new specimens of lepisosteoids, consisting of 5 vertebrae and 24 teeth obtained by sifting. The teeth have acrodin cap and apicobasal ridges, whereas the vertebrae have opisthocoelous centra; one of the vertebrae do not exhibit the pattern of centra compression of the lepisosteid vertebral series. Vertebrae and teeth are diagnostic of Lepisosteoidea and Lepisosteidae, respectively. The materials represent the first occurrence of the referred groups in the Cenomanian of Maranhão and expand the previously known lepisosteid record of South America.

Keywords: Teeth, Vertebrae, Morphogical description, Cajual Island.
\end{abstract}

\section{RESUMO}

Nova ocorrência de restos de lepisosteídeos (LEPISOSTEIFORMES: LEPISOSTEOIDEA) do Cenomaniano da Formação Alcântara (Cretáceo Superior), estado do Maranhão, Brasil

Lepisosteoidea é uma superfamília de Lepisosteiformes. Seus representantes, popularmente conhecidos como gars, são divididos em duas famílias: Lepisosteidae e Obaichthyidae. Afloramentos da Formação Alcântara (Cenomaniano) descobertos ao longo da costa do estado do Maranhão, Nordeste do Brasil revelaram uma diversa ichthyofauna, na qual a ocorrência de Lepisosteiformes foi atribuída a Lepidotes sp. baseada na descrição morfológica de escamas ganóides isoladas. Descrevemos aqui novos espécimes de lepisosteóides, consistindo de 5 vertebras e 24 dentes obtidos através de peneiramento. Os dentes apresentam ápice de acrodina e cristas apicobasais e as vertebras apresentam centros opistocélicos; uma das vertebras não exibe o padrão de compressão da série vertebral dos lepisosteídeos. Vertebras e dentes são diagnósticos de Lepisosteoidea e Lepisosteidae, respectivamente. O material representa a primeira ocorrência dos referidos grupos no Cenomaniano do Maranhão e expandem o registro de lepisosteídeos na América do Sul.

Palavras-chave: Dentes, Vértebras, Descrição morfológica, Ilha do Cajual.

\section{INTRODUTION}

Lepisosteiformes (Ginglymodi) is a group of neopterygian fishes found in North and Central Americas and Caribbean Islands, though the group was more widespread and diverse during the Mesozoic and Paleogene times (Grande, 2010; López-Arbarello, 2012; Nelson et al., 2016). Within the Lepisosteiformes clade is included the superfamily Lepisosteoidea. Its representatives, popularly known as gars, are divided in two families: Lepisosteidae, that includes the extant forms of gars and its earliest record dated back to Late Jurassic, and Obaichthyidae, restricted to Early Cretaceous (López-Arbarello, 2012; Brito et al., 2017). The earliest known Lepisosteioidea is considered a marine taxon, in contrast with all other fossil lepisosteoids.

Isolated materials such as scales and teeth represent the most common fossil remains of gars, 
and in addition to the few lepisosteoid vertebrae, they provide an important record favoring the understanding of the historic distribution of the group (Moody \& Sutcliffe, 1991; Gottfried \& Krause, 1998; Kear et al., 2009; Divay \& Murray, 2015; Martinelli \& Teixeira, 2015; Pérez-García et al., 2016; Szabó et al., 2016; Alves et al., 2020; Kovalchuk \& Anfimova, 2020). The vertebrae with opisthocoelous centra and teeth with plicidentine are useful for identifying fragmentary fossil specimens, once they are diagnostic for Lepisosteoidea and Lepisosteidae, respectively (Grande, 2010; López-Arbarello, 2012). Few studies described a significative sample of lepisosteoid vertebrae, revealing the patterns of parapophyses orientation and centra compression along the vertebral series of the group (see Grande, 2010; Szabó et al., 2016).

The Alcântara formation is a lithostratigraphic unit that comprises a $35-\mathrm{m}$ succession of sandstones and pelitic deposits related to an incised valley filling, dated as Cenomanian (Pedrão et al., 1993; Klein \& Ferreira, 1997; Rossetti \& Truckenbrodt, 1997). The Alcântara formation outcroppings were discovered along the Maranhão state coast in Northeastern Brazil, and they revealed a diverse ichthyofauna, at which the Lepisosteiformes occurrence was attributed to Lepidotes sp. based on morphological descriptions of isolated ganoid scales. (Carvalho \&
Santos, 1992; Medeiros \& Schultz, 2001; Medeiros et al., 2014). Scales have been used to identify Lepidotes sp. worldwide; however, because isolated ganoid scales are shared by different clades such as the Semionotiformes and Lepisosteiformes, their taxonomic attribution can be erroneous (LópezArbarello, 2012; Meunier et al., 2016; Bittencourt et al., 2017).

Based on teeth and vertebrae morphologies, we register herein a new occurrence of Lepisosteidae in the Cenomanian (Upper Cretaceous) of the Alcântara Formation, Maranhão, expanding the previously known South America Cenomanian record for the group.

\section{MATERIALS AND METHODS}

The specimens described herein comprise 24 teeth and five vertebrae of fishes from the Falésia do Sismito ( $2^{\circ} 28^{\prime} 56,31^{\prime \prime} \mathrm{S}$; $\left.44^{\circ} 28^{\prime} 09,57^{\prime \prime} \mathrm{O}\right)$, an outcrop of the Alcântara formation at Cajual Island in Maranhão state, Northeastern Brazil (Figure 1).

The specimens were obtained through sediment sifting of samples collected in 2003 and stored at the fossil collection of the Centro de Pesquisa de História Natural e Arqueologia do Maranhão (CPHNAMA), where they were registered as VT-1541 (teeth) and VT-1540 (vertebrae). Their descriptions were based

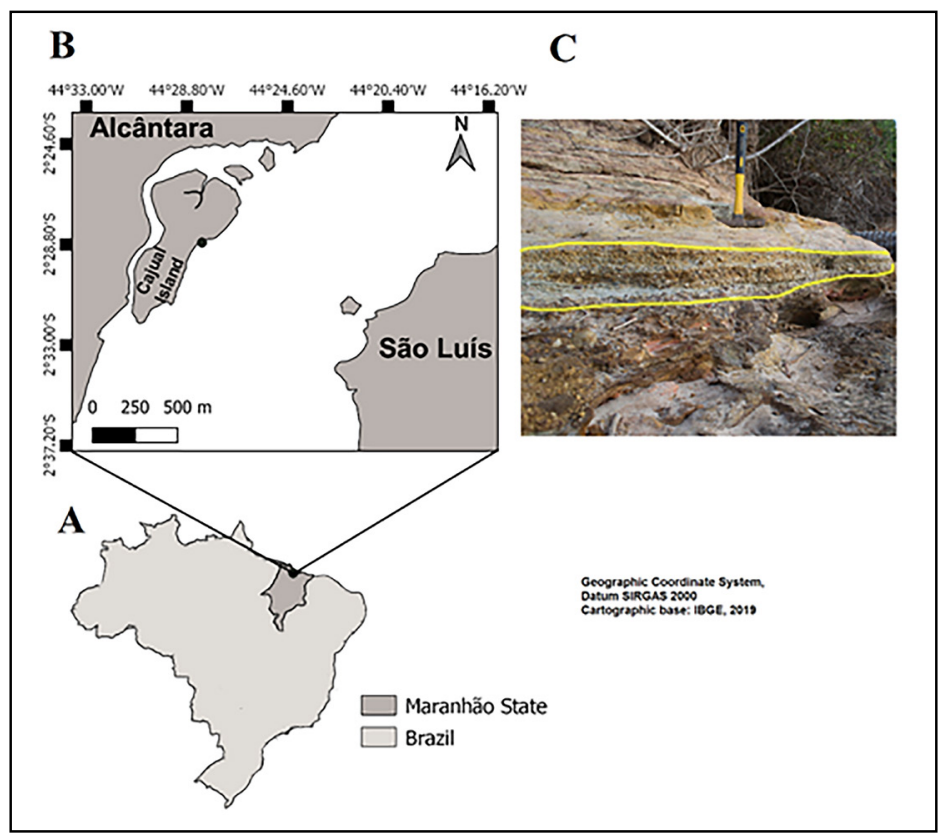

Figure 1. The fossiliferous site. A, Maranhão state, Northeast Brazil. B, Falésia do Sismito (black dot), Cajual Island, Alcântara. C, Detail of the Falésia do Sismito outcrop and the level from which the materials described herein were collected (between yellow lines). 
on Grande (2010) monography; and Divay \& Murray (2015), which pertain to details of the vertebrae neural and haemal arches, with some nomenclatural differences.

The diagnosis was conducted according to Grande (2010) study, using taxonomic arrangements proposed by López-Arbarello (2012), such as the adoption of the superfamily Lepisosteoidea (Obaichthyidae + Lepisosteidae), previously referred to as Lepisosteiformes.

\section{RESULTS}

VT-1541 consists of 24 conical teeth, apicobasally tall, and slightly curved, reaching its maximal thickness at the base (Figure 2). They show apicobasal-oriented ridges at their bases and acrodin cap with a distinctive "translucent red" color on the apex. The acrodin cap translucent aspect contrasts with the rest of the teeth, which vary in color among the specimens or even within a same specimen with shades of red, brown, and white. The apicobasal-oriented ridges vary in length between the specimens, from being restricted to the tooth base in some specimens (Figure 2A) to reaching one third of the tooth in others. The conspicuity of the ridges also varies; in some specimens they are well-pronounced (Figure 2B) and in others they are almost imperceptible (Figure 2A). Based on these characteristics and literature comparative analysis it is possible to determinate that these structures belong to Lepisosteidae.

VT-1540 consists of five abdominal vertebrae with hourglass shaped opisthocoelus centra (Figure 3 ). Most specimens presented only the bases of the lateral parapophyses and ventral haemal arches preserved.

The vertebrae VT-1440-1, VT-1540-2, VT1540-3 and VT-1540-4 have $9 \mathrm{~mm}, 10 \mathrm{~mm}, 10 \mathrm{~mm}$ and $9 \mathrm{~mm}$ in length, respectively; they are long and tall. Their elongated aspects suggest that they belong to the end of the abdominal series. VT-1540-5 has $3 \mathrm{~mm}$ in length and the others dimensions with similar extent. The centra dorsal surfaces, when preserved, bears a pair of longitudinal parasagittal processes, that enclose the neural canal and separate

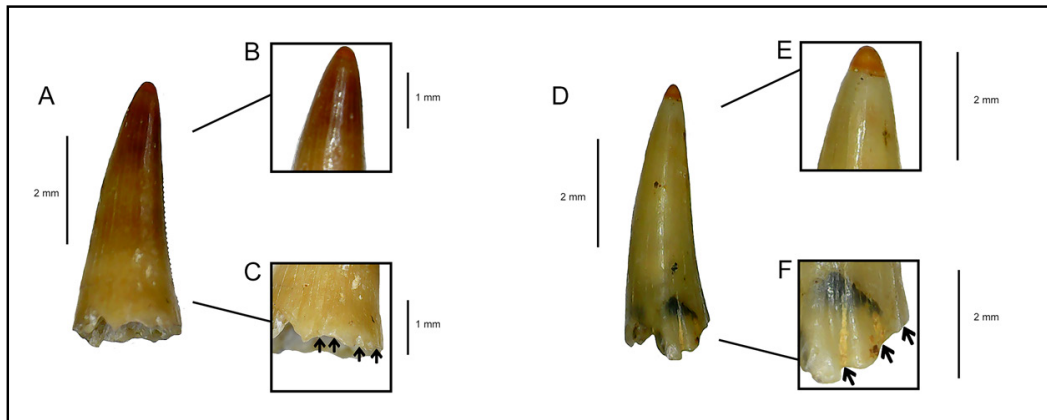

Figure 2. AD, Lepisosteid teeth from the Upper Cretaceous (Cenomanian) of the Alcântara Formation (Maranhão, Brazil). BE, acrodin cap detail. CF, apicobasal ridges detail.
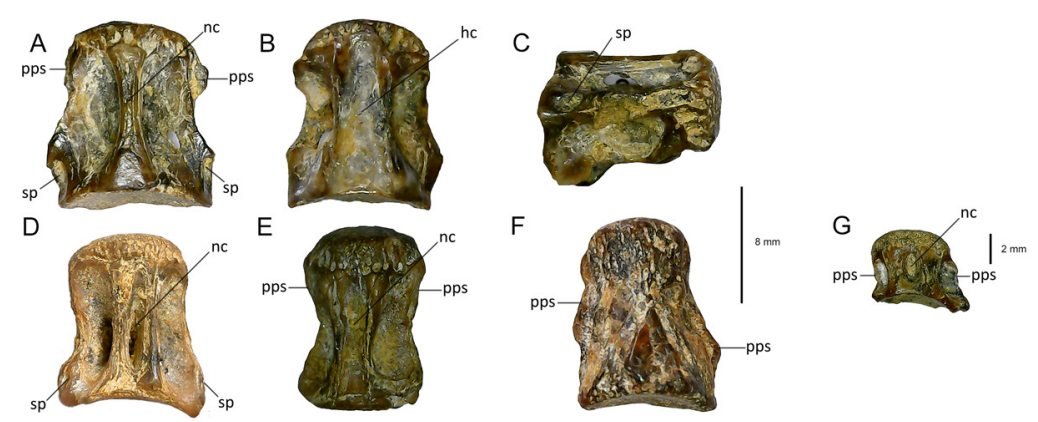

Figure 3. Lepisosteoid vertebrae from the Upper Cretaceous (Cenomanian) of the Alcântara Formation (Maranhão, Brazil). ABC, VT-1540-1 in dorsal, ventral and lateral right views. DEFG, VT-1540-2, VT-1540-3, VT-1540-4, and VT-1540-5 in dorsal view. Parapophysis, pps; neural canal, nc; haemal canal, hc; small pit, sp. 
two lateral shallow fossae. The neural canals vary in width among the specimens, and in some cases, it is so small that the specimen appears to bear only one longitudinal parasagittal process. Similarly, the centra ventral surfaces bears two longitudinal parasagittal processes that enclose the haemal canal and separate two lateral shallow fossae. The haemal canals also vary in width in the examined specimens. The haemal canals of the specimens are wider than their neural arch.

A lateral bar separates the dorsal and ventral surfaces. In VT-1440-1 and VT-1540-2 it bears a small pit on its posterior region. In posterior view (Figure 5), it is possible to observe the lateral bar and parapophyses vestiges, that vary in orientation. In most specimens they are laterally oriented (Figure $5 \mathrm{ABCD}$ ), except one in which the orientation is lateroventral (Figure 5E). Based on these characteristics and literature comparative analysis it is possible to determinate that these structures belong to Lepisosteoidae.

\section{DISCUSSION}

Although the specimens are incomplete, they exhibit a combination of features that are enough to allow their identification. The vertebrae have opisthocoelous centra, a distinctive character of Lepisosteoidea (López-Arbarello, 2012). Though they could belong to different taxa within the clade, their differences are probably due to their topography, ontogenetic variation and phylogenetical position. The teeth have the typical lepisosteid aspect with acrodin cap and apicobasal oriented ridges (Gottfried \& Krause, 1998; Pérez-García et al., 2016; Szabó et al., 2016; Alves et al., 2020). The ridges represent external expressions of the internal dentine folds, called plicidentine, and within lepisosteoids they are exclusive to Lepisosteidae (Grande, 2010).

Grande (2010) studied the vertebral elements of the extant Lepisosteus osseus, Linnaeus, 1758 ,and Atractosteus spatula, Lacepède, 1803, and showed that the parapophyses on the anterior abdominal centra are projected laterally whereas the parapophyses on the posterior abdominal centra are ventrally projected. In addition, the centra become laterally compressed in the posterior elements of the vertebral series (Figure 4). The same pattern was observed in Atractosteus sp. from the Upper Cretaceous of Hungary (Szabó et al., 2016). Isolated and incomplete vertebrae are assembled in VT-1540 and any precise ordering of the vertebrae relative position would be hypothetical. The specimens have only the parapophyses bases preserved (Figure 5ACDE), except one in which the whole structures were absent (Figure 5B). Nevertheless, in the specimen where the parapophyses were not preserved, the position of the lateral bar could indicate their possible orientation. The vertebrae exhibit the centrum compression pattern of the lepisosteid vertebral series. However, the vertebrae with lateroventrally oriented parapophyses do not

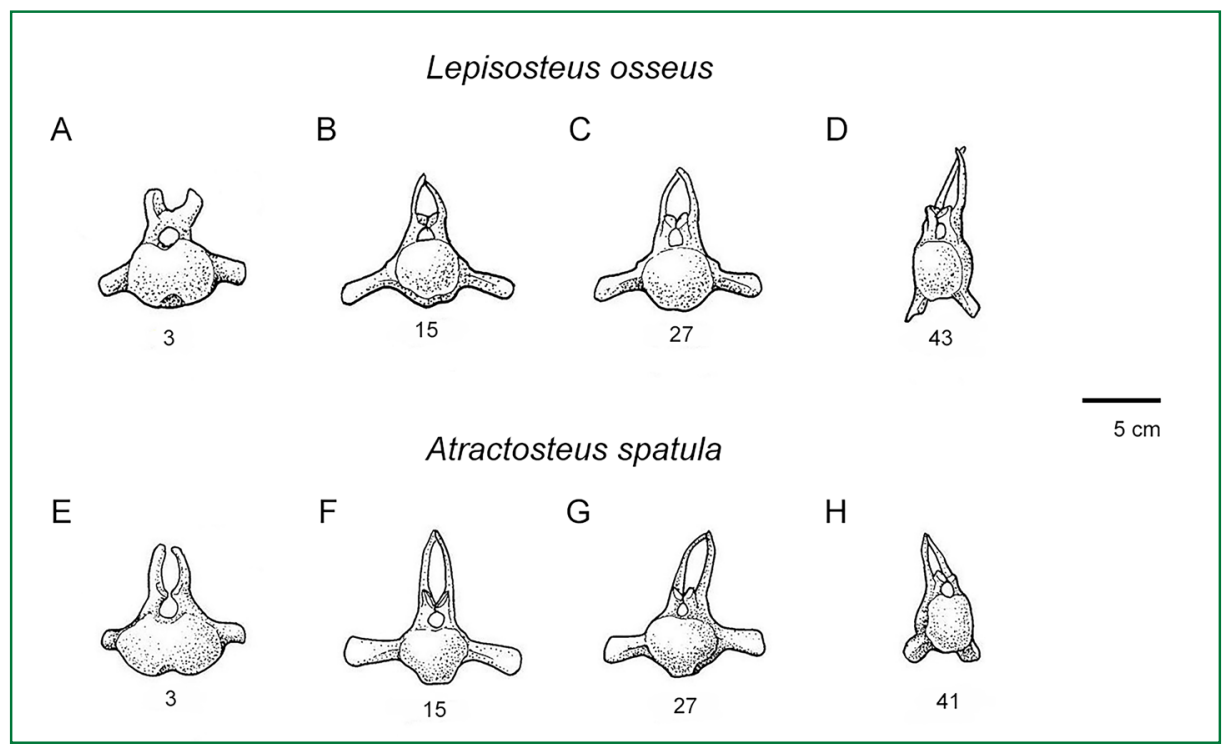

Figure 4. Lepisosteid vertebrae showing the pattern of parapophyses orientation and centra compression along the vertebral abdominal series. The numbers indicate the position of the vertebra on the vertebral series. Modified from Grande (2010). 


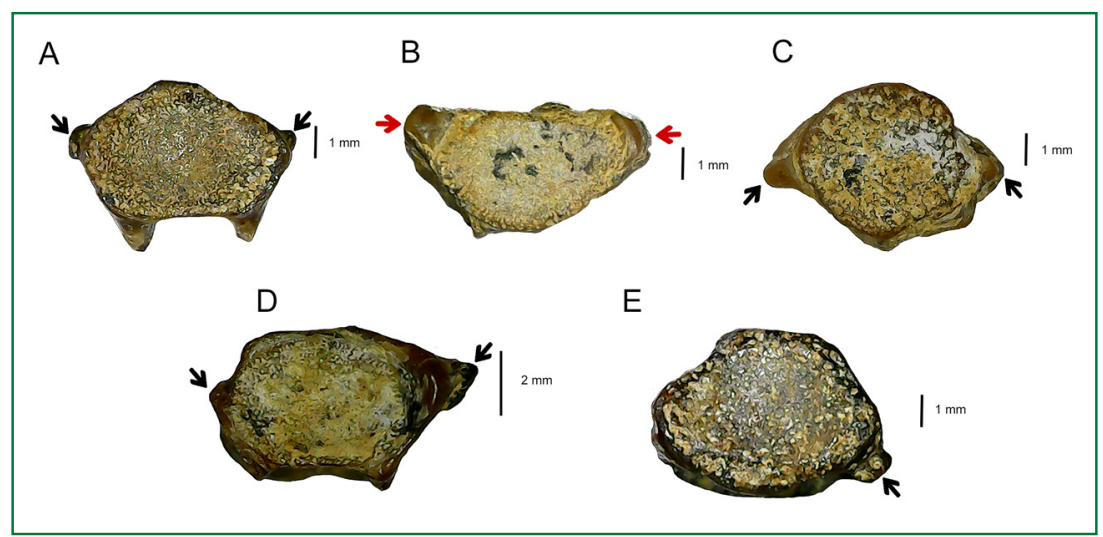

Figure 5. Lepisosteoid vertebrae from the Upper Cretaceous (Cenomanian) of the Alcântara Formation (Maranhão, Brazil) in posterior view. A, VT-1540-1. B, VT-1540-2. C, VT-1540-3. D, VT-1540-5. E, VT-1540-4. Parapophysis (black arrow); lateral bar (red arrow).

have laterally compressed centrum (Figure 5E); this contrasts with the previously mentioned pattern. Again, because of the fragmentary nature of the examined sample, these details are difficult to access and further studies based on best-preserved materials are required to clarify the differences in the centrum compressions described herein.

The external morphologic aspects of isolated scales were used to identify Lepidotes sp. from the Cenomanian of Maranhão (Carvalho \& Santos, 1992; Medeiros \& Schultz, 2001; Medeiros et al., 2014). However, morphological features, such as microtubercles on the ganoine surface and histological details, which can help with taxonomic identification, were not analyzed in the referred studies. Additionally, ganoid scales characters could be homoplastic, which can make taxonomic attribution based solely on isolated specimens erroneous (López-Arbarello, 2012; Meunier et al., 2016; Bittencourt et al., 2017). Therefore, the occurrence of Lepidotes sp. in the Cenomanian of Maranhão cannot be determined with certainty and some scales may belong to other taxa. Taking into account the lepisosteid material described herein some of the scales previously referred to Lepidotes sp. could actually belong to Lepisosteidae.

\section{ACKNOWLEDGMENTS}

The authors would like to thank the Centro de Pesquisa de História Natural e Arqueologia do Maranhão (CPHNAMA) staff, particularly Agostinha Pereira for providing the facilities, equipments and the sedimentary rock samples that yielded the specimens herein studied. We also thank the
CPHNAMA trainees who partake in the sifting of the sedimentary material.

\section{REFERENCES}

ALVES, Y.M, MONTEFELTRO, F.C. \& CIDADE, G.M. (2020). New occurrences of Atractosteus (Ginglymodi: Lepisosteoidea: Lepisosteidae) from the Bauru Group (Upper Cretaceous, Brazil) and paleobiogeographic implications. Cretaceous Research, 121.

BITTENCOURT, J.S., GALLO, V. \& RODRIGUES, G. A. (2017). Lepisosteoid-type fish scales in the Barremian-Aptian (Lower Cretaceous) of the Sanfranciscana Basin, Southeastern Brazil. Cretaceous Research, 70, 1-7.

BRITO, P.M., ALVARADO-ORTEGA, J. \& MEUNIER, F.J. (2017). Earliest known lepisosteoid extends the range of anatomically modern gars to the Late Jurassic. Scientific Reports, 7 (17830), 1-8.

CARVALHO, M.S.S. \& SILVA, V.G. (1992). Ocorrência de escamas de Lepidotes (Pisces) na Formação Itapecuru, Cretáceo da Bacia de São Luís, Estado do Maranhão, Brasil. An. Aca. Bras. de Ciên., Rio de Janeiro, 64 (4), 419.

DIVAY, J.D. \& MURRAY, A. M. (2015) The late Eocene-early Oligocene ichthyofauna from the Eastend area of the Cypress Hills Formation, Saskatchewan, Canada. Jour. Vert. Pal., 35 (4), e956877.

GOTTFRIED, M.D. \& KRAUSE, D. W. (1998) First record of gars (Lepisosteidae, Actinopterygii) on Madagascar: Late Cretaceous remains from the 
Mahajanga Basin. Jour. Vert. Pal., 18 (2), 275-279.

GRANDE, L. (2010) An empirical synthetic pattern study of gars (Lepisosteiformes) and closely related species, based mostly on skeletal anatomy: the resurrection of Holostei. Am. Soc. Icht. Herp., 2010, ed. 2, 1-888.

KEAR, B.P., RICH, T.H., ALI, M.A., ALMUFARRIH, Y.A., MATIRI, A.H., AL-MASARY, A.M. \& ATTIA, Y. (2009) An Upper Cretaceous (Campanian-Maastrichtian) actinopterygian fish assemblage from the marginal marine Adaffa Formation of Saudi Arabia. Cretaceous Research, 30 (5), 1164-1168.

KLEIN, V.V. 7 FERREIRA, C.S. (1979) Paleontologia e Estratigrafia de uma fácies estuarina da Formação Itapecuru, Estado do Maranhão. An. Aca. Bras. de Ciên., 51, 523-533.

KOVALCHUK, O.M. \& ANFIMOVA, G.V. (2020) Lepisosteiform Fish (Holostei) Ganoid Scales from the Middle Jurassic Deposits of Ukraine. Zoodiversity, 54 (1), 35-42.

LÓPEZ-ARBARELLO, A. Phylogenetic Interrelationships of Ginglymodian Fishes (Actinopterygii: Neopterygii). PLoS ONE, 7 (7), $1-44$.

MARTINELLI, A.G. \& TEIXEIRA, V.P.A. (2015) The Late Cretaceous vertebrate record from the Bauru Group in the Triângulo Mineiro, southeastern Brazil. Bol. Geo. Min., 126(1), 129-158.

MEDEIROS, M.A., LINDOSO, R.M., MENDES, I.D. \& CARVALHO, I. de S. (2014) The Cretaceous (Cenomanian) continental record of the Laje do Coringa flagstone (Alcântara Formation), Northeastern South America. Jour. South Am. Ear. Sci., 53, 50-58.

MEDEIROS, M.A. \& SCHULTZ, C.L. (2001) Uma paleocuminidade de vertebrados do Cretáceo médio, Bacia de São Luís. In: ROSSETI, D. F.; GÓES, A. M.;
TRUCKENBRODT, W. (Editores). O Cretáceo na Bacia de São Luís-Grajaú. Coleção Friedrich Katzer, Museu Paraense Emílio Goeldi, Belém, 209-221.

MEUNIER, F.J., EUSTACHE, R.P., DUTHEIL, D. \& CAVIN, L. (2016) Histology of ganoid scales from the early Late Cretaceous of the Kem Kem beds, SE Morocco: systematic and evolutionary implications. Cybium, 40 (2), 121-132.

MOODY, R.T.J. \& SUTCLIFFE, P.J.C. (1991) The Cretaceous deposits of the Iullemmeden Basin of Niger, central West Africa. Cretaceous Research, 12, 137-157.

NELSON, J.S., GRANDE, T.C. \& WILSON, M.V.H. (2016). Fishes of the world. 5. ed. Hoboken, New Jersey: John Wiley \& Sons, Inc.. 751 p.

PEDRÃO, E., ARAI, M. \& CARVALHO, I. de S., SANTOS. (1993). Palinomorfos da Formação Itapecuru - análise palinológica de uma amostra de superfície da Ponta do Farol, São Luís - MA. Petrobras, Relatório Técnico 1, Rio de Janeiro, 10 p. PÉREZ-GARCÍA, A., ORTEGA, F., BOLET, A., ESCASSO, F., HOUSSAYE, A., MARTÍNEZSALANOVA, J., MIGUEL-CHAVES, C. de, MOCHO, P., NARVÁEZ, I., SEGURA, M., TORICES, A. \& VIDAL, D. (2016). A review of the upper Campanian vertebrate site of Armuna (Segovia Province, Spain). Cretaceous Research, 57, 591-623.

ROSSETTI, D.F. \& TRUCKENBRODT, W. (1997). Revisão estratigráfica para os depósitos do Albiano-Terciário Inferior (?) na Bacia de São Luís, Maranhão. Bol. Mus. Par. Em. Goe., Belém, sér. Ciências da Terra 9, 29-41.

SZABÓ, M., GULYÁS, P. \& ÓSI, A. (2016). Late Cretaceous (Santonian) Atractosteus (Actinopterygii, Lepisosteidae) remains from Hungary (Iharkút, Bakony Mountains). Cretaceous Research, 60, 239-252. 